\title{
The Lived Experiences of Ngā Tāne Māori with Hip and Knee Osteoarthritis
}

\author{
Te Whatarangi Dixon BHSC \\ Physiotherapist, Queen Elizabeth Hospital, Rotorua, New Zealand
}

Daniel W. O'Brien PhD

Senior Lecturer, Department of Physiotherapy; Active Living and Rehabilitation: Aotearoa New Zealand, Health and Rehabilitation Research Institute, School of Clinical Sciences, Auckland University of Technology, Auckland, New Zealand

\section{Gareth Terry PhD}

Centre for Person Centred Research, Auckland University of Technology, Auckland, New Zealand

\section{Jennifer N. Baldwin PhD}

Postdoctoral Fellow, Priority Research Centre in Physical Activity \& Nutrition, Faculty of Health and Medicine, The University of Newcastle, Australia

Tom Ruakere DHSC

School of Clinical Sciences, Auckland University of Technology, Auckland, New Zealand

Toni Mekkelholt BHSC

Physiotherapist, Whakatane Hospital, Whakatane, New Zealand

Peter J. Larmer DHSC

Head of School, School of Clinical Sciences, Auckland University of Technology, Auckland, New Zealand

\section{ABSTRACT}

Osteoarthritis (OA) is a debilitating condition affecting an individual's quality of life in multiple ways. However, little is known about the experiences of tāne (men) Māori living with OA in Aotearoa New Zealand. We aimed to explore the lived experiences of ngā tāne Māori with OA. This qualitative study was guided by tikanga and kaupapa Māori philosophies. Interviews were conducted in a semi-structured method, with seven tāne Māori living with OA. Key themes were identified and developed from the data through thematic analysis, and were informed by Tā Mason Durie's Māori health frameworks, Te Whare Tapa Whā and Te Pae Māhutonga. Four themes developed from the data and were named: (1) The interface of masculine embodiment and mana, (2) Taha whānau and connection as central to ngā tāne Māori wellbeing, (3) The benefits of taha wairua (spiritual wellbeing), and (4) Te urutau kia uru ki te punaha tiaki hauora: Adapting to access the health-care system. OA places a significant burden on ngā tāne Māori and their whānau, impacting on all aspects of hauora (health). The unique lived experiences and impact on wider whānau of Māori living with OA indicates the need to consider te ao Māori (Māori world view) when developing clinical services and a Model of Care for OA.

\section{Dixon, T.-W., O’Brien, D. W., Terry, G., Baldwin, J. N., Ruakere, T., Mekkelholt, T. \& Larmer, P. J. (2021). The lived experiences of ngā tāne Māori with hip and knee osteoarthritis. New Zealand Journal of Physiotherapy, 49(3), 127-133. https://doi.org/10.15619/NZJP/49.3.03}

Key Words: Aotearoa New Zealand, Beliefs, Experiences, Tāne (men) Māori, Osteoarthritis

\section{INTRODUCTION}

Osteoarthritis $(\mathrm{OA})$ is a common joint disease that affects the health and wellbeing of approximately one in 10 people living in Aotearoa New Zealand and costs the country an estimated $\$ 12$ billion annually (Deloitte Access Economics, 2018). People with OA often experience pain, joint stiffness and weakness, which can affect their mobility, independence, function and mental wellbeing (Hall et al., 2008). Research suggests that ngā tāne (men) Māori suffer higher incidence and prevalence rates of OA than non-Māori males (Ministry of Health, 2019), although Jansen et al. (2009) state Māori may be underestimated in statistics. Māori are more likely to undergo total joint replacements at a younger age, present with greater preoperative comorbidities and have more postoperative complications than non-Māori (Pai et al., 2010; Singleton et al., 2013).

OA can affect all aspects of a person's sense of hauora (health) including taha hinengaro (mental and emotional), taha tinana (physical) and taha whānau (social) (Durie, 2004; Gignac et al., 2008; Hawker et al., 2011; Jolly et al., 2017; Kao \& Tsai, 2012; McGruer et al., 2019; Smythe et al., 2012; Smythe \& White, 2017). International guidelines state that management of the disease should be patient-centred and address the multifaceted nature of the condition (National Institute for Health and Care Excellence, 2021). Furthermore, a call has been made for a New Zealand Model of Care for OA that details how, when, 
where and with whom the management of OA should happen (Baldwin et al., 2017; O'Brien et al., 2021).

Māori perspectives have historically been under-reported in research in Aotearoa New Zealand and few studies have employed kaupapa Māori methods that facilitate manaenhancing practice (Smith, 1999). McGruer et al. (2019) explored the lived experience of ngā wāhine (females) Māori with $O A$, and found that OA inflicts a substantial burden on the physical, mental, spiritual and family wellbeing of Māori. The authors argue that primary care practitioners must consider spiritual and family wellbeing when providing care for Māori with OA (McGruer et al., 2019). However, it is unclear if the findings also represent ngā tāne Māori. Therefore, we aimed to explore the perceptions and lived experiences of ngā tāne Māori living with $\mathrm{OA}$ in Aotearoa New Zealand.

\section{METHODS}

\section{Study design}

This study used a qualitative method and was informed by the kaupapa Māori philosophical framework for research (Smith, 1999).

\section{Kaupapa Māori philosophical framework}

The kaupapa Māori research model is Māori-centred, with outcomes aiming to benefit Māori. Kaupapa Māori research is defined as "to engage in a dialogue about setting new directions for the priorities, policies, and practices of research for, by and with Māori" (Smith, 1999, p. 183). It places Māori values, customs and protocols at the centre of the research methods, and is vital in attaining an accurate interpretation of te ao Māori to ensure mana-enhancing approaches to research practice (Jones et al., 2006).

\section{Participants}

The study was advertised via social media and flyers as well as through the primary researcher's (TD) whānau, community contacts and snowball sampling. Participants were recruited from the Bay of Plenty region. Participants were included if they identified as tāne Māori, were over the age of 35 years and met the American College of Rheumatology criteria for hip or knee OA; knee, hip or groin pain; stiffness for less than 30 min; knee crepitus; bony tenderness and enlargement of the knee; and no unusual, palpable warmth (Kolasinski et al., 2020). Participants were excluded if they had difficulty verbally communicating in either English or te reo Māori; had suffered a significant injury in the past 3 months; had had a total joint replacement; or had a disability or medical condition other than OA that substantially affected their daily function.

\section{Procedures}

Participants were interviewed face to face by TD in a location of the participant's choosing. Upon starting, karakia (ritual chant or prayer) was undertaken, the consent form was filled out and whakawhanaungatanga (process of building relationships) established. The interviews followed a semi-structured style in both English and te reo Māori. TD utilised the domains of te ao Māori to ensure tikanga (Māori customs) where karakia, whakawhanaungatanga, manaakitanga (process of showing respect), aroha (love and compassion) and pono (honesty) were included. These tikanga practices safeguarded the research process, results, researchers and participants (Jones et al., 2006). The questions were open-ended (see Appendix A), aiming to explore the participants' personal experience of $\mathrm{OA}$ and their experience of health services. Five of the seven participants asked that their interviews not be recorded - two of the participants did not want their voices to be loaded onto any shared networks and no reason was given for the other three participants. Interviews that were not digitally recorded were instead transcribed by TD, from extensive notes written during the interview, then further developed and transcribed immediately following the interview to aid in the retention of important details. The remaining two interviews were recorded and transcribed verbatim.

Data analysis

Analysis was guided by the six steps outlined by Terry et al. (2017) for reflexive thematic analysis. Consideration of te ao Māori informed and shaped the process of developing themes throughout the research process. The first step involved familiarisation, making casual notes on the content of the interviews. Inductive codes were then generated, informed by the research question at both semantic and latent levels (the latter often using concepts from mātauranga Māori to inform codes). From this, themes were developed, tested and reviewed by returning to the interviews to determine whether they accurately gauged the data collected, then the final report was produced. Each of the six phases of thematic analysis were carried out by the primary researcher, with findings presented to the wider research team. Following this, the themes were refined by a second member of the research team (GT) and again presented to the research team to ensure that meaning had been retained.

Theme development was informed by the Māori health frameworks, Te Whare Tapa Whā and Te Pae Māhutonga. Te Whare Tapa Whā (Durie, 1998) uses the four walls of a whare (house) that represent the elements that symbolise good health and wellbeing. Te Pae Māhutonga is a health promotional framework, also proposed by Durie (2004). A constellation, Te Pae Māhutonga or Southern Cross, has traditionally guided Māori on their ocean voyages. The stars that make up Te Pae Māhutonga symbolically represent the components of Durie's (2004) health promotion framework: Mauriora, Waiora, Toiora, Te Oranga, Nga Manukura and Te Mana Whakahaere, which served historically as a guide for generations of Māori.

\section{RESULTS AND DISCUSSION}

Seven tāne Māori participated in the study and their ages ranged from 49 to 75 years. Five participants had knee OA and two had hip OA. Symptom duration ranged from 6 months to 40 years. Four participants lived rurally and three lived in an urban area. All participants indicated taking medication for their OA and four stated that they used rongoa (traditional Māori medicine) to treat their OA. Four themes developed from the data and were named: (1) The interface of masculine embodiment and mana, (2) Taha whānau and connection as central to ngā tāne Māori wellbeing, (3) The benefits of taha wairua (spiritual wellbeing), and (4) Te urutau kia uru ki te punaha tiaki hauora: Adapting to access the health-care system. 
Theme 1: The interface of masculine embodiment and mana

This theme explored the different beliefs ngā tāne Māori expressed regarding their mana, in relation to their 'manliness' or masculinity, and how this was impacted by OA. Central to this theme was the relationship of masculine identity to both taha tinana and taha hinengaro, and the inseparability of these within te ao Māori. Taha hinengaro allows people to think, communicate and feel, generating awareness of the self (Durie, 1998) - but this includes experiences and expressions of the physical body. Within Western men's health literature, this interface has been understood as experiential embodiment (Robertson et al., 2010). This is an area underexplored within Western biomedicine, where the body and mind are often treated as separate (Robertson et al., 2010), something that can impact ngā tāne Māori negatively. For the men in this study, taha hinengaro seemed to be a primary point of reference for understanding the experience of OA. However, how this manifested in their roles and responsibilities (toiora) as tāne Māori was also referred to throughout the interviews.

Frequently, the sensation of whakamā (an event or experience that brings shame or embarrassment) was present for ngā tāne Māori when talking about their experiences of OA (Te Karu, 2013):

It's just annoying to be honest. A lot of things have changed ... The things I used to be able to do, I just can't ... I can't run anymore, I can walk but I struggle to keep up with people ... It's tough because I'm still relatively young ... It just bothers me feeling like people are looking at me with pity. (Participant 5)

Participants commonly expressed attitudes associated with the dominant ideals and values of Aotearoa New Zealand: strong, hard-working, rising above adversity and, most notably, humility (Phillips \& Hulme, 1987). Participants spoke of being a "man's man", and having a "she'll be right" attitude, drawing on the powerful imaginary figure of the 'kiwi bloke', who epitomises what an Aotearoa New Zealand man should look like and aspire to be (Terry \& Braun, 2009). A predominant feature of this whakamā was the reluctance to be vulnerable. Ngā tāne Māori seemed to struggle with a concern for burdening others and the disempowering feeling of pity from whānau and friends. This had significant effects on their mana. Mana as an expression of spiritual power and potentiality within a person (Tate, 2010), seemed at risk due to their experiences. This was spoken about by some of ngā tāne Māori specifically in relation to their masculinity:

I can't bring myself to get too emotionally involved, I've always been a man's man and just gotten on with life. My kids are all doing really well with my moko's [mokopuna/ grandchildren] so I don't want to be annoying them. (Participant 2)

I've never really thought about it ... I'm definitely a man's man, I've always just done things a certain way and was brought up with my dad's 'life isn't fair' way. I don't really talk about these things because we were basically raised to be staunch and all. (Participant 5)
In contrast, some ngā tāne Māori articulated their mana or masculinity as not defined by their physical capacity alone, and were more willing to be vulnerable and accepting of change: "Having ailments is a natural thing. Your maleness isn't judged on whether you're limp winged or have any other physical defect" (Participant 3).

Despite these differences in ngā tāne Māori, there was a distinct sense that they were answerable to these masculinity concerns, whether or not they identified strongly with them. This meant that ngā tāne Māori would often make reference to manhood and masculinity when speaking about OA and its impacts, whether or not this was raised by the interviewer.

Much of this kōrero related to changes in toiora (role expectations and changes) and the modelling of skills and behaviour to their whānau. This often meant that the elements of their identities that gave them a sense of meaning were increasingly being located in the past, rather than the present.

I really miss my hunting ... that's what I miss the most. Getting my boys and the dogs, then just spending a day or two out in the bush with them. It's priceless those moments ... They're memories I will cherish forever; it's the time I spent with my boys bringing them up and teaching them the life skills that were passed down to me. It's whakapapa really my boy. (Participant 6)

This kind of embodiment has been described as pragmatic embodiment - or the ways the body enables certain roles (father, worker, rugby player) to be taken up (Robertson et al., 2010). For ngā tāne Māori like Participant 6, this was inextricably tied to their bodies. For some ngā tāne Māori, their roles had changed as they aged, and so the need for physical expression of masculinity was lessened: "When I go and help with the marae and that, it doesn't really affect me. Although, I've got to sit down a bit ... I still partake in that sort of thing it hasn't stopped me doing that" (Participant 4).

For those whose identities were tied up in their physicality, this was something that seemed to be a longstanding component of their lives. Ngā tāne Māori spoke of the comparisons between the freedom of youth and their current experience of their bodies:

It's all part of life. I was just a kid, I still am young at heart even though I'm an old fart and can't do much anymore ... We would go up the hills and roll down them, run down to the beach and build huts and play rugby in the mud. (Participant 6)

These conversations and comparisons seemed to be confronting for some participants. This could indicate a reliance on their bodies for a positive sense of self. Several ngā tāne Māori had not previously considered, or had and disregarded, the implications of their physical ailments on their mental wellbeing. This may highlight a challenge when supporting ngā tāne Māori to express their vulnerabilities.

I do sometimes get a little bit, well maybe more than a little bit ... How do I put it? Not depressed. Oh, actually a little bit of that I think ... You know, putting up with the pain. It's 
hard to say ... You know, when I feel and look at my bad knee I think, Jesus what's going on. (Participant 4)

Taha tinana considers our autonomy over our physical health and how we manage the challenges presented to this and is strongly related to our mental wellbeing (taha hinengaro). Turning to whānau for support in times of need is common; so, it is essential we consider the nuances of taha whānau and the role of connection.

Theme 2: Taha whānau and connection as central to ngā tāne Māori well being

Whānau in te ao Māori is tremendously important. Durie (1998) argues the concept of whānau is unique, as it organises Māori culture and is foundational to Māori identity. There are two elements that characterise taha whānau. First, whānau is the principal support system. Second, self-reliance and an insistence on independence, not turning to whānau for support in times of need, is viewed as immaturity rather than strength. As Durie (1998) states, "Interdependence rather than independence is the healthier goal" (p. 72). This idea is extended to connection to whenua (land) and whakapapa (genealogy), and the support these offer ngā tāne Māori and their sense-making concerning OA.

'Mauri', means life force, in things or objects both living and inanimate. In essence, 'mauri ora' expresses the importance of a healthy cultural identity, to realise inner potential and to seek one's identity and facilitation into te ao Māori (Durie 1999; 2004). For many Māori, urbanisation has limited access into te ao Māori. Many Māori have become alienated, as cultural ties have been damaged through the confiscation of whenua, generational loss of te reo Māori, colonised suppression and institutionalised racism (Jones et al., 2006). The loss of cultural identity and its impacts on wellbeing were evident among some participants in the dataset:

I was brought up in the city but we used to go out to the farm back home all the time when I was growing up ... I was beaten when I was younger for speaking Māori even though it's my native tongue. (Participant 2)

All participants discussed how important their whānau were and the crucial role they played in their lives. However, several ngā tāne Māori struggled or were reluctant to engage emotionally with whānau about their OA. This could indicate the breakdown in mauri ora, with some ngā tāne Māori unwilling to open up in fear of becoming a burden on others, emphasising again the challenge ngā tāne Māori have with vulnerability: "I don't really talk about it with them ... It's just become the norm now really, me being a cripple. My kids and I joke about it so it's not too depressing" (Participant 5)

Some ngā tāne Māori appeared to have strong connections with whānau and whakapapa, speaking of their whānau as Durie (1998) describes: "family is the primary support system for Māori, providing care and nurturance, in physical terms as well as culturally and emotionally" (p. 86). Muriwai et al. (2015) further argue that those who strongly identify solely as Māori, with strong cultural adeptness, have lower psychological distress. Our data supports this notion, for instance: "My whānau support me 100 percent, they are the reason I am who
I am. Their opinions are the only opinions that matter most to me. If anything, they help me through each and every day" (Participant 7).

Ngā tāne Māori in this study discussed how their roles had changed within their whānau and society due to ageing. It is a natural human instinct to seek acceptance and to have a place of belonging within society (Oetzel et al., 2019). Hence, the endeavours of te oranga is to find that sense or place of belonging, in order to participate in society (Durie, 2004). Ngā tāne Māori felt their ability to participate in society or with whānau had become limited due to their OA. These limitations include the changing dynamics as a pāpā (father) or koroua (grandfather), and the inability to work full-time or at all, drive, stand at the marae or simply hang the washing.

I used to be able to help the boys at mahi [work], but now I have to drive the truck around to all the areas and just wait for them as we go through each paddock or bush ... I can't go out hunting like I used to as well, because my knee just hurts too much. (Participant 1)

When speaking of these changes, ngā tāne Māori allowed out a part of their compartmentalised emotions. These were raw, special moments, which showed they had the capacity to express their vulnerabilities: "I tell you what though, the thing I really miss is actually being able to run around with the kids" (Participant 5).

The main thing I miss the most is being able to ride my horse ... I can't ride him like I used to ... My knee bloody kills me when there in the stirrups, it just jars-up and crunches with every stride. It's the worst pain. (Participant 1)

Ngā tāne Māori have struggled with the changes brought on by $\mathrm{OA}$, including choosing to be independent from whānau, living and working alongside whānau or seeking a spiritual connection. Hence, taha wairua needs to be discussed, as Māori culture is infused intimately with the spiritual world.

Theme 3: The benefits of taha wairua (spiritual wellbeing) Taha wairua encapsulates the unspoken energies that surround us. It is intertwined with the past, present and future and provides the important connections Māori have with their whakapapa and te ao Māori (Durie, 1998). Waiora is one's capacity to balance and harmonise one's relationship with one's environment. Durie $(1999,2004)$ emphasises the significance of environmental protection and the relationship with te ao Māori, and how it is crucial for the health and wellbeing of Māori. The two important factors required to bring balance with the spiritual realm are tikanga and āhuatanga Māori. If tikanga Māori are 'Māori customs' then āhuatanga Māori are 'Māori traditions', and co-exist with one another. Āhuatanga Māori in particular is key, as it encompasses the characteristics of Māoritanga that connect the deep emotional and spiritual bonds unique to Māori (Mead, 2003).

Typically, Māori are raised under tikanga and āhuatanga Māori. Our results suggest that rural ngā tāne Māori appear to have a stronger connection to their wairua compared to urban ngā tāne Māori, which could be due to the effects of urbanisation: "I'd go for drives to the bush where I used to go hunting ... to 
listen to all of Tāne-mahuta's children singing their songs and let my thoughts drift away. Sometimes I'd fall asleep" (Participant 1).

In comparison, Participant 7 was from an urban setting: "Never tried rongoa ... I wasn't brought up around that stuff. If we were sick or got injured we went to the doctors, that's just the way it was" (Participant 7).

Some urban-raised ngā tāne Māori mournfully expressed they had not been back to their papakāinga (ancestral homelands) in many years, which resulted in them feeling disconnected from their whenua, iwi and tīpuna (ancestors): "If I'm feeling a bit down about something, all my whānau live back home so I don't really have that many people to talk to. I'm divorced now and the kids are all grown up" (Participant 2).

Urbanisation has profoundly impacted the upbringing of Māori and their access to te ao Māori. Many Māori who feel disconnected from their wairua become more socially isolated and have experienced generational marginalisation in the Aotearoa New Zealand healthcare system (Jansen et al., 2009). Participants in this study have experienced different types of healthcare treatment; hence, it is critical to discuss these experiences.

Theme 4: Te urutau kia uru ki te punaha tiaki hauora: Adapting to access the health-care system Numerous studies have argued Māori marginalisation in the Aotearoa New Zealand health-care system, and the disparity between the biomedical/Western and Māori models of health (Elers, 2014; Wilkins, 2009). Ngā tāne Māori in this study reported contrasting experiences of the healthcare system. Ngā tāne Māori with a stronger sense of identity, support and belonging appeared to have had positive experiences especially if their medical professionals' practices matched their expectations:

Oh, the good thing they do here is they treat you like whānau. They always make sure we are okay, they would contact you and make you feel at home here, which [I think is] different to what it's like in the cities. (Participant 4)

However, others reported stories of institutional racism and marginalisation, for instance:

I grew up in a pohara [poor] neighbourhood and the doctors treated us like we were from a third world country ... I got annoyed one time when my mum was sick. The doctors saw all the pākehā patients who arrived after us ... I was 12 or 13 at the time and I threw my marbles at him when he came out and we left. We moved to another doctor after that and we've had the same family doctor ever since. (Participant 7)

Furthermore, some discussed the disconnect between the pākehā/biomedical approach, which traditionally they felt focused on the physical symptoms of health, and the holistic approach of te ao Māori. This divide in Aotearoa New Zealand healthcare institutions was perfectly summarised by Participants 1 and 3: "Never really been a big fan of doctors boy. Everything to do with the pākehā way of life is just different to our life. Not to say one is better than the other, just different" (Participant 1).
Our people are not used to talking about their mamae [pain]. Perhaps, our medical professionals would need to learn how to get that information out of us rather than write 'now okay we'll give you this for that, and this for that. All right, thank you very much. See you later, good day.' Then they walk out and pay $\$ 50$ for that service. (Participant 3)

OA has made a significant impact on ngā tāne Māori. To others, they present the dominant ideals that are perceived to epitomise what an Aotearoa New Zealand ngā tāne Māori should be. However, many spoke about struggling to come to terms with their condition(s) and become accepting of these changes, in private. Durie (1998) advises considering all dimensions collectively and not independently. But this is difficult to achieve with ngā tāne Māori with ill-health or injury. Throughout each dimension, a major issue became evident: the inability for some participants to accept change and unwillingness to express their vulnerabilities.

\section{Strengths and limitations}

A strength of the study was the guidance of kaupapa Māori throughout the research process; the key utilisation of the Māori health frameworks informed the data analysis and theme development. Having the primary researcher (TD) and a second member (TR) of the research team identify as Māori and understand tikanga and kaupapa Māori protocols was fundamental to implementation of concepts of te ao Māori. A limitation of this study was the small sample size, which should be considered when interpreting the results. Additionally, only two of the seven interviews were digitally recorded at the request of participants. Therefore, some communications may have been lost due to recall limitations.

\section{Clinical and research implications}

Physiotherapists and researchers should consider the process of whanaungatanga as a method of building rapport when undertaking research with or treating ngā tāne Māori. This change could be something as simple as committing time at the beginning of the session to understanding what is important to your patient/participant and sharing something about yourself. For more guidance, please see Person and whānau centred care / seeing the patient as a person / ethnicity Māori (Darlow \& Williams, 2018) on the Physiotherapy New Zealand website.

\section{CONCLUSION}

This is the first kaupapa Māori-informed study of the lived experience of hip and knee OA by ngā tāne Māori in Aotearoa New Zealand. The findings emphasise the multifaceted and integrated nature of hauora Māori. The physical and emotional burden of OA has impacted on ngā tāne Māori perceptions of themselves, and caused some to question their masculinity. Furthermore, OA impacts the relationships and roles of ngā tāne Māori within both their whānau and in society. The unique lived experiences and wider whānau impacts of ngā tāne Māori living with OA supports the need to consider the necessities of te ao Māori into clinical practice and future OA models of care.

\section{KEY POINTS}

1. OA can affect the ability for ngā tāne Māori participation with whānau, which can in turn impact their sense of selfworth and mana. 
2. OA affects ngā tāne Māori relationships and roles within both their whānau and in society.

3. Physiotherapists should consider the process of whanaungatanga to build rapport when treating ngā tāne Māori.

\section{DISCLOSURES}

There are no conflicts of interest that may be perceived to interfere with or bias this study.

\section{PERMISSIONS}

This study was granted ethical approval by the Auckland University of Technology Ethics Committee (reference number 18/389)

\section{ACKNOWLEDGEMENTS}

The authors would like to acknowledge the support of PersonCentred Research (AUT) for funding the summer student scholarship that underpinned this project.

\section{ADDRESS FOR CORRESPONDENCE}

Daniel O'Brien, Department of Physiotherapy, School of Clinical Sciences, Auckland University of Technology, Auckland, New Zealand.

\section{Email: dobrien@aut.ac.nz}

\section{REFERENCES}

Baldwin, J., Briggs, A. M., Bagg, W., \& Larmer, P. J. (2017). An osteoarthritis model of care should be a national priority for New Zealand. New Zealand Medical Journal, 130(1467), 78-86.

Deloitte Access Economics. (2018). The economic cost of arthritis in New Zealand in 2018: Arthritis New Zealand. https://www.arthritis.org. nz/wp-content/uploads/2018/09/Economic-cost-of-Arthritis-in-NewZealand-2018.pdf

Darlow, B., \& Williams, A.; on behalf of the Professional Development Committee. (2018). Person and whānau centred care. Physiotherapy New Zealand. https://pnz.org.nz/Category?Action=View\&Category_id=1136

Durie, M. (1998). Whaiora: Māori health development (2nd ed.). Oxford University Press.

Durie, M. H. (1999). Te Pae Māhutonga: A model for Māori health promotion. Health Promotion Forum of New Zealand Newsletter 49. https://www.cph.co.nz/wp-content/uploads/TePaeMahutonga.pdf

Durie, M. (2004). An Indigenous model of health promotion. Health Promotion Journal of Australia, 15(3), 181-185. https://doi.org/10.1071/ HE04181

Elers, P. (2014). Māori health: Issues relating to health care services. Te Kaharoa, 7(1), 163-172. https://doi.org/10.24135/tekaharoa.v7i1.51

Gignac, M. A. M., Backman, C. L., Davis, A. M., Lacaille, D., Mattison, C. A., Montie, P., \& Badley, E. M. (2008). Understanding social role participation: What matters to people with arthritis? Journal of Rheumatology, 35(8), $1655-1663$.

Hall, M., Migay, A.-M., Persad, T., Smith, J., Yoshida, K., Kennedy, D., \& Pagura, S. (2008). Individuals' experience of living with osteoarthritis of the knee and perceptions of total knee arthroplasty. Physiotherapy Theory and Practice, 24(3), 167-181. https://doi.org/10.1080/09593980701588326

Hawker, G., Gignac, M. A. M., Badley, E., Davis, A. M., French, M. R., Li, Y., Perruccio, A. V., Power, J. D., Sale, J., \& Lou, W. (2011). A longitudinal study to explain the pain-depression link in older adults with osteoarthritis Arthritis Care \& Research, 63(10), 1382-1390. https://doi.org/10.1002/ acr.20298
Jansen, P., Bacal, K., \& Crengle, S. (2009). He ritenga whakaaro: Māori experiences of health services. Mauri Ora Associates. https://www.moh. govt.nz/notebook/nbbooks.nsf/0/2A6CAF401ABBEFB9CC2575F4000B6D0 C/\$file/He-Ritenga-Whakaaro.pdf

Jolly, J., Bassett, S. F., O’Brien, D., Parkinson, C., \& Larmer, P. J. (2017). An exploration of the sequence and nature of treatment options available to people living with osteoarthritis of the hip and/or knee within a New Zealand context. New Zealand Journal of Physiotherapy, 45(2), 90-95.

Jones, R., Crengle, S., \& McCreanor, T. (2006). How tikanga guides and protects the research process: Insights from the hauora tāne project. Social Policy Journal of New Zealand Te Puna Whakaaro, 29, 60-77. https:// www.msd.govt.nz/documents/about-msd-and-our-work/publicationsresources/journals-and-magazines/social-policy-journal/spj29/29pages-60-77.pdf

Kao, M.-H., \& Tsai, Y.-F. (2012). Living experiences of middle-aged adults with early knee osteoarthritis in prediagnostic phase. Disability and Rehabilitation, 34(21), 1827-1834. https://doi.org/10.3109/09638288.20 12.665127

Kolasinski, S. L., Neogi, T., Hochberg, M. C., Oatis, C., Guyatt, G., Block, J., Callahan, L., Copenhaver, C., Dodge, C., Felson, D., Gellar, K., Harvey, W. F., Hawker, G., Herzig, E., Kwoh, C. K., Nelson, A. E., Samuels, J., Scanzello, C., White, D., ... Reston, J. (2020). 2019 American College of Rheumatology/Arthritis Foundation guideline for the management of osteoarthritis of the hand, hip, and knee. Arthritis \& Rheumatology, 72(2), 220-233. https://doi.org/10.1002/art.41142

McGruer, N., Baldwin, J. N., Ruakere, B. T., \& Larmer, P. J. (2019). Māori lived experience of osteoarthritis: A qualitative study guided by kaupapa Māori principles. Journal of Primary Health Care, 11(2), 128-137. https://doi. org/10.1071/HC18079

Mead, M. (2003). Tikanga Māori: Living by Māori values. Huia Publications.

Ministry of Health. (2019). Annual update of key results 2017/18: New Zealand Health Survey. https://www.health.govt.nz/publication/annualupdate-key-results-2017-18-new-zealand-health-survey

Muriwai, E. M., Houkamua, C. A., \& Sibley, C. G. (2015). Culture as cure? The protective function of Māori cultural efficacy on psychological distress. New Zealand Journal of Psychology, 44(2), 14-24. https://mro.massey. ac.nz/handle/10179/11792

National Institute for Health and Care Excellence. (2021). Osteoarthritis. Quality Standard (June, 2015). https://www.nice.org.uk/guidance/qs87/ resources/osteoarthritis-pdf-2098913613253

O’Brien, D., Pigg, W., Ellis, R., Baldwin, J., Quicke, J., Evans, N., \& Dziedzic, K. (2021). An evidence-informed model of care for people with lower limb osteoarthritis in New Zealand. New Zealand Journal of Physiotherapy, 49(1), 24-30. https://doi.org/10.15619/NZJP/49.1.04

Oetzel, J. G., Hokowhitu, B., Simpson, M., Reddy, R., Nock, S., Greensill, H., Cameron, M. P., Meha, P., Johnston, K., Harding, T., Shelford, P., \& Smith, L. T. (2019). Kaumātua Mana Motuhake: A study protocol for a peer education intervention to help Māori elders work through later-stage life transitions. BMC Geriatrics, 19(1), 36. https://doi.org/10.1186/s12877019-1041-2

Pai, V., Pai, V., \& Wright, S. (2010). Differences in outcome between Māori and Caucasian patients undergoing total joint arthroplasty for osteoarthritis. Journal of Orthopaedic Surgery, 18(2), 195-197. https://doi. org/10.1177/230949901001800212

Phillips, J., \& Hulme, K. (1987). Te whenua, te iwi = The land and the people Allen \& Unwin/Port Nicholson Press/Stout Research Centre.

Robertson, S., Sheikh, K., \& Moore, A. (2010). Embodied masculinities in the context of cardiac rehabilitation. Sociology of Health \& IIIness, 32(5), 695-710. https://doi.org/10.1111/j.1467-9566.2010.01249.x

Singleton, N., Buddicom, E., Vane, A., \& Poutawera, V. (2013). Are there differences between Māori and non-Māori patients undergoing primary total hip and knee arthroplasty surgery in New Zealand? A registry-based cohort study. New Zealand Medical Journal, 126(1379), 23-30. 
Smith, L. T. (1999). Decolonizing methodologies: Research and indigenous peoples. Zed Books Ltd; University of Otago Press.

Smythe, E., Larmer, P. J., \& McNair, P. J. (2012). Insights from a physiotherapist's lived experience of osteoarthritis. Physiotherapy Theory and Practice, 28(8), 604-616. https://doi.org/10.3109/09593985.2011.6 54320

Smythe, E., \& White, S. G. (2017). Methods of practice: Listening to the story. Physiotherapy Theory and Practice, 33(6), 462-474. https://doi.org/10.108 0/09593985.2017.1318989

Tate, H. A. (2010). Towards some foundations of a systematic Māori theology: He tirohanga anganui ki ētahi kaupapa hōhonu mō te whakapono Māori [Doctoral dissertation]. Melbourne College of Divinity. https://repository.divinity.edu.au/530/1/2010PhD_Tate\%2CH_Towards_ Some_Foundations_of_a_Sustematic_Maori_Theology.pdf
Te Karu, L., Bryant, L., \& Elley, C. R. (2013). Māori experiences and perceptions of gout and its treatment: A kaupapa Māori qualitative study. Journal of Primary Health Care, 5(3), 214-222. https://doi.org/10.1071/ HC13214

Terry, G., \& Braun, V. (2009). 'When I was a bastard': Constructions of maturity in men's accounts of masculinity. Journal of Gender Studies, 18(2), 165-178. https://doi.org/10.1080/09589230902812463

Terry, G., Hayfield, N., Clarke, V., \& Braun, V. (2017). Thematic analysis. In C. Willig \& W. Rogers (Eds.), The SAGE handbook of qualitative research in psychology (pp. 17-36). SAGE Publications. https://doi. org/10.4135/9781526405555.n2

Wilkins, D. (2009). Men's health around the world: A review of policy and progress across 11 countries. Journal of Men's Health, 6(3), 272. https:// doi.org/10.1016/j.jomh.2009.08.175

\section{APPENDIX A}

\section{INDICATIVE QUESTIONS}

Can you start by telling me about the history of your [knee/hip] pain?

What, if anything, has been the impact of your [knee/hip] pain on your life?

What, if anything, have you done about your [knee/hip] pain?

How do you manage your knee/hip pain on a day-to-day basis?

Has your [knee/hip] pain affected your relationships with other members of your whānau? If so, how?

Has your [knee/hip] pain impacted on your [physical/ mental/ spiritual] health and wellbeing? If so, how?

How do you feel about your [knee/hip] pain, now and into the future?

What is your knowledge of osteoarthritis in terms of the condition itself?

What are your thoughts about medication/pain relief in relation to your knee/hip pain? (Talk about different kinds of medication and how they are used).

What sorts of traditional/complementary/alternative approaches do you use? How have you found these?

There are a number of ideas about Kiwi masculinity (being stoic, self-reliant, etc.). How do you relate to these?

How does being a guy influence some of your thinking about pain and management of pain?

What has been your experience of doctors and other health practitioners (broadly defined) prior to OA?

Has the experience of having OA impacted on how you relate to doctors and other health practitioners? If so, how? 